\title{
ANALISIS PERSEPSI DAN PREFERENSI PENGUNJUNG EMBUNG A SEBAGAI KOMPONEN PENGELOLAAN EMBUNG DI INSTITUT TEKNOLOGI SUMATERA
}

\section{Analysis Perception and Preferences in Lake "Embung A" as a Component of Landscape Management in Institut Teknologi Sumatera}

\section{Rizka Nabilah}

Program Studi Arsitektur Lanskap, Jurusan Infrastruktur dan Kewilayahan, Institut Teknologi Sumatera

Email: rizka.nabilah@arl.itera.ac.id

\author{
Rian Adetiya Pratiwi \\ Program Studi Arsitektur Lanskap, \\ Jurusan Infrastruktur dan Kewilayahan, \\ Institut Teknologi Sumatera \\ Email: rian.pratiwi@arl.itera.ac.id
}

\section{Cipta Vidyana}

Program Studi Arsitektur Lanskap, Jurusan Infrastruktur dan Kewilayahan Institut Teknologi Sumatera

Email: cipta.vidyana@arl.itera.ac.id

\section{ABSTRACT}

Institut Teknologi Sumatera (ITERA) has an artificial lake reservoir, called an embung. This embung requires landscape management for the purpose of conserving water resources. This embung functions as a water storage area to anticipate water shortages in the dry season and water runoff problems in the rainy season. This management process is related to the concept of coordinating the embung landscape, visitors and policy makers from ITERA. Management of the embung landscape is needed as a part of the evaluation of the physical maintenance and ideal maintenance of the embung. The purpose of this study is to prepare recommendations for lake management as a sustainable blue open space in ITERA. From these data, it is obtained data on perceptions of the management response of the existing reservoir. The questionnaire will be directed to determine the visitor's concern for the management of Embung A ITERA. Statistical data analysis was performed based on Pearson correlation analysis. The results showed that $82.2 \%$ of visitors 'understanding of landscape management was related to policy analysis and visitors' perceptions of embung with a value of $80.6 \%$. From these data it is known that the management link with the highest value is maintaining the cleanliness of the environment of Embung A ITERA, namely the perception of visitors with a value of 0.95 (positive).

Keywords: blue open space, Embung A ITERA, Institut Teknologi Sumatera, landscape management, recommendation.

\section{PENDAHULUAN}

Institut Teknologi Sumatra (ITERA) adalah institusi baru yang berlokasi di Jalan Terusan Ryacudu, Way Hui, Kecamatan Jati Agung, Kabupaten Lampung Selatan, Lampung. ITERA memiliki lanskap kampus yang unik, yaitu terdapat beberapa kolam retensi, yang disebut embung. Salah satu embung yang paling banyak dikunjungi adalah Embung A. Embung A direncanakan sebagai lokasi rekreasi, karena terletak di depan kampus ITERA. Kegiatan rekreasi dapat dikategorikan sebagai dampak sosial dari jasa ekosistem (Kulczyk, Woźniak, dan Derek, 2018). Beberapa faktor tentang pengunjung pada suatu lokasi rekreasi adalah jumlah pengunjung, karakteristik, tujuan, jenis kegiatan, dan latar belakang sosial pengunjung (Damanik dan Helmut, 2006). Rekreasi adalah kegiatan dari dampak yang muncul dari jasa ekosistem kompleks melibatkan berbagai bidang dan jasa lingkungan yang penting. Oleh karena itu, butuh pendekatan tentang kompleksitas jasa ekosistem yang mengintegrasikan perspektif lingkungan dan sosial ekonomi. Konsep jasa ekosistem telah dikembangkan dengan mengintegrasikan manfaat sosial, ekologi dan ekonomi dari jasa lingkungan.

Rekreasi yang dilakukan di luar ruangan dapat diklasifikasikan sebagai jasa ekosistem budaya yang didefinisikan sebagai hal yang tidak konsumtif yang dapat mempegaruhi fisik dan mental seseorang. Hal tersebut dapat menjadi dampak positif pada proses fisiologis dan pemulihan stres emosional. Sehingga,meningkatnya permintaan pada rekreasi di luar ruangan dan semakin meningkatnya beragam kegiatan rekreasi. Sehingga, perlu adanya upaya strategi untuk membangkitkan strategi pengelolaan lanskap yang efektif. Manajemen yang sukses tergantung pada ketersediaan informasi yang dapat dipercaya, misalnya latar belakang budaya dan sosiodemografis. Preferensi itu dapat diciptakan dengan membangun perilaku spasial dan aktual masyarakat di dalam lanskap (Komossa et al., 2020).

Faktor pengalaman alami masyarakat dalam sebuah lanskap meliputi pengalaman psikologis menilai estetika ruang (Suckall et al., 2009). Manfaat emosional terkuat tentang pengalaman pada lanskap yang emosional. Penelitian tentang lanskap yang restoratif dipandang dari sisi psikologi, harus memiliki empat komponen, yaitu berada pada posisi yang jauh (memberikan kesan pergeseran konseptual secara spasial), lanskap harus memiliki cakupan yang luas untuk berpikir tenang, daya tarik (lingkungan memberikan stimulus yang menarik) dan memiliki kompatibilitas (Sever dan Verbič, 2019).

Faktor keberlanjutan rekreasi berdasarkan jasa lingkungan melibatkan proses interkoneksi antara berbagai penggunaan lahan pada skala yang berbeda, hal ini berkaita dengan dimensi spasial (Ramyar, 2019). Permasalahan embung yang dihadapi oleh institusi ITERA adalah belum adanya Standar Operasional Prosedur (SOP) untuk pegelolaan yang tepat. Dengan demikian, pada praktiknya Embung ITERA menghadapi berbagai faktor masalah mulai dari bio-fisik hingga masalah manusia sebagai pengunjung. Sehingga, perlu adanya analisis pengelolaan masalah (Komossa et al., 2020).

Oleh karena itu, perencanaan dan pengelolaan untuk keberlanjutan lanskap yang potensial sebagai area rekreasi membutuhkan pengetahuan sosial dan pendekatan ekologis (Raymar, 2019). Dari perspektif budaya, lanskap danau memiliki peradaban manusia pada lingkungan hidup perkotaan yang penting (Lin, Homma, dan Iki, 
2018). Lanskap tersebut dapat berfungsi sebagai sumber untuk pariwisata dan pendidikan lingkungan. Dalam beberapa dekade terakhir, aktivitas manusia semakin meningkat serta telah mengakibatkan kerusakan parah pada lanskap danau (Genever et al., 2003).

Dalam pengelolaan lanskap perlu ada analisis yang lebih luas antara kebutuhan geografis, penggunaan lahan, dan karakter sosial pengunjung. Oleh karena itu, tujuan dari penelitian ini adalah untuk mengetahui persepsi dan preferensi pengunjung tentang kegiatan yang dilakukan di Embung A ITERA dan mengembangkan rekomendasi untuk pengelolaan rekreasi di Embung A ITERA.

\section{METODE PENELITIAN}

\section{Lokasi dan Waktu Penelitian}

Lokasi penelitian di Embung A ITERA, yang terletak di Jalan Terusan Ryacudu, Desa Way Hui, Kabupaten Jatiagung, Lampung. Lokasi penelitian berada pada koordinat lintang $5^{\circ} 21^{\prime} 27,58$ "S dan bujur $105^{\circ} 18 ' 46,85^{\prime \prime} \mathrm{T}$ (Gambar 1). Penelitian ini dilakukan pada bulan Mei-Juli 2019. inventarisasi dengan pengamatan bio-fisik Embung A ITERA. Tahap kedua adalah distribusi kuesioner kepada 100 responden secara random sampling. Responden diambil dengan kriteria acak yang berkunjung ke Embung A. Pengunjung secara acak terpilih sesuai dengan kesediaan waktu untuk mengisi kuesioner. Tahap ketiga adalah analisis persepsi dan preferensi pengunjung mengenai fungsi Embung A ITERA.

Penyusunan kuesioner juga melibatkan uji validitas, berdasarkan karakteristik kuesioner dengan penelitian tindakan partisipatif. Kemudian, pertanyaan di dalam kuesioner mengikuti situasi perspektif masyarakat untuk rekreasi. Penyusunan kuesioner ini membutuhkan waktu sekitar 3 minggu, dari Juni 1 hingga 21 Juni 2019. Kuesioner terdiri dari 10 bab pertanyaan, yaitu data pribadi pengunjung, kegiatan pengunjung di Embung A, persepsi bio-fisik, persepsi terkait dengan kenyamanan dan keamanan, persepsi yang terkait dengan visual dan audio, persepsi terkait dengan kebijakan, preferensi desain, preferensi vegetasi, partisipasi pengunjung dalam keterlibatan pengelolaan, dan saran untuk pengelolaan embung. Pertanyaan dalam kuesioner dikategorikan

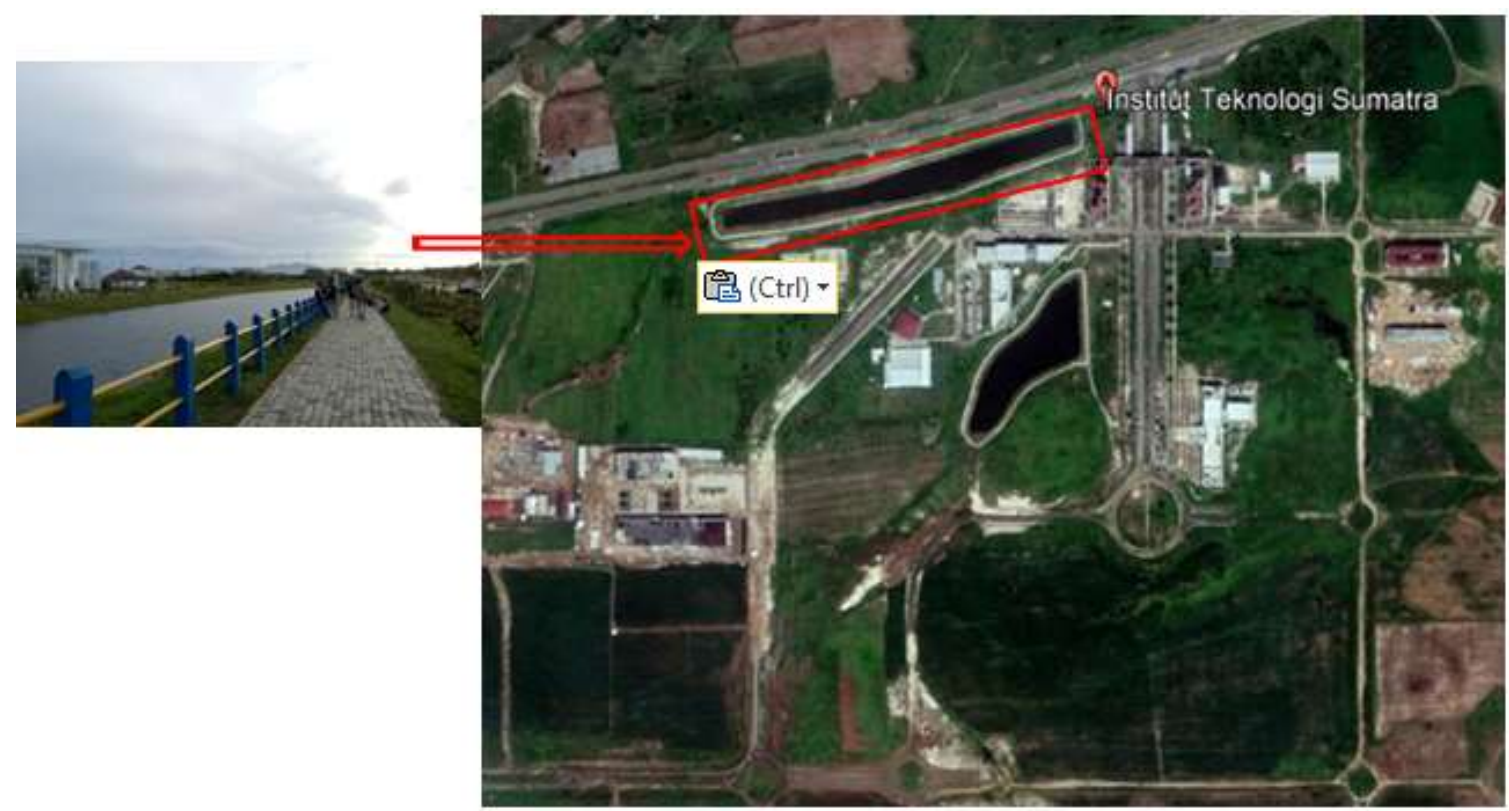

Gambar 1. Lokasi Penelitian

\begin{abstract}
Alat dan Bahan
Alat yang digunakan terbagi menjadi dua, yaitu alat dari perangkat keras dan lunak. Perangkat keras yang digunakan adalah lembar survei, lembar kuisioner, Kamera digital, dan Global Positioning System (GPS). Perangkat lunak yang digunakan adalah computer software SPSS (Statistical Package for the Social Sciences) atau perangkat lunak untuk proses analisis data statistika.
\end{abstract}

\section{Metode Analisis Data}

Penelitian ini dilakukan dengan menyebarkan kuesioner kepada 100 pengunjung di Embung A ITERA. Penelitian ini menggunakan analisis data kombinasi. Proses analisis dilakukan dengan menggabungkan data kuantitatif dan kualitatif. Data kualitatif diperoleh dari penilaian bio-fisik Embung A ITERA dan hasil analisis dari lembar wawancara. Data kuantitatif yang diperoleh dari kuesioner pengunjung dianalisis dengan analisis statistik uji validitas dan reliabilitas. Tahap pertama adalah kembali dengan kode PP1 hingga PP12, dengan penjelasan sebagai berikut; PP1 adalah persepsi terhadap kebersihan; PP2 adalah persepsi pengunjung terhadap keindahan; PP3 adalah persepsi pengunjung terhadap pemeliharaan; PP4 adalah persepsi pengunjung terhadap faktor pencegahan masalah; PP5 adalah persepsi pengunjung terhadap pengelolaan limbah; PP6 adalah persepsi pengunjung terhadap komponen pengelolaan; PP7 adalah persepsi pengunjung terhadap partisipasi aktif masyarakat; PP8 adalah persepsi pengunjung terhadap faktor pengelolaan secara umum; PP9 adalah persepsi pengunjung terhadap pengelolaan fisik Embung A; PP10 adalah persepsi pengunjung terhadap faktor retribusi keuangan pada Embung A; PP11 adalah persepsi pengunjung terhadap faktor kesetujuan pembayaran tiket ke Embung A; dan PP2 adalah persepsi pengunjung terhadap pengelolaan keseluruhan. 


\section{HASIL DAN PEMBAHASAN}

\section{Gambaran Umum Lokasi Penelitian}

Embung A ITERA direncanakan sebagai tempat rekreasi dan area untuk mendukung ruang terbuka hijau di mana terletak di depan gerbang ITERA (Gambar 2a). Pengelolaan lanskap merupakan hal yang penting bagi Embung A ITERA, karena merupakan bagian pengelolaan area retensi di ITERA (Gambar 2b). Itu menunjukkan bahwa daerah sekitar Embung A jika tidak dikelola dengan baik, menimbulkan kesan estetika yang buruk pada tengara logo ITERA (Gambar 2b). Aturan umum yang terdapat di Embung A ITERA tidak diperbolehkan untuk kegiatan membuang sampah, tidak diperbolehkan memancing, dan kegiatan vandalisme (Gambar 2c). Peraturan tersebut sudah berjalan dan ditetapkan. Embung A ITERA memiliki pemandangan yang indah, tetapi ada tanaman liar yang mengganggu aliran air (Gambar 2d).

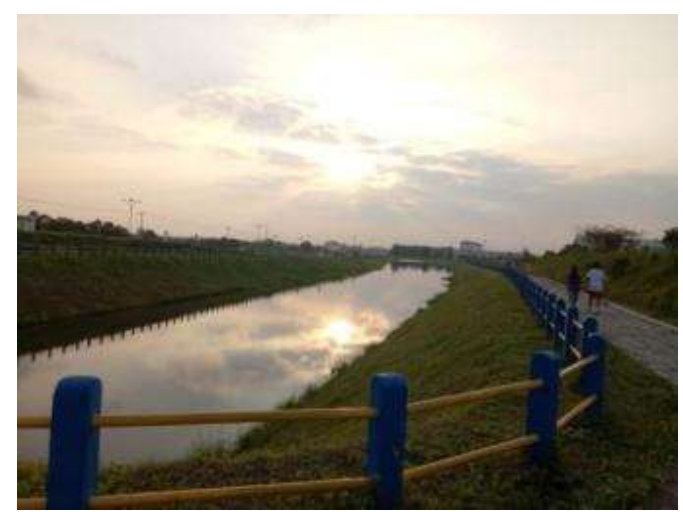

a. Pemandangan Embung A ITERA

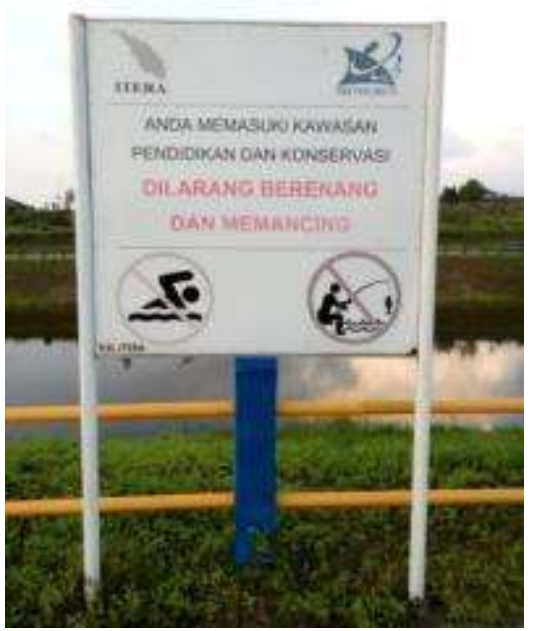

c. Peraturan di Embung A ITERA hari Sabtu sore, Minggu Pagi, dan Minggu Sore. Hasil penelitian menunjukkan bahwa dominasi pengunjung adalah wanita dengan rentang usia 13-19 tahun. Hasilnya menunjukkan pengunjung wanita $49 \%$, responden pria $41 \%$, dan tanpa keterangan sekitar 10\%. 10\% responden tidak mengisi jenis kelamin dalam pengisian kuesioner (Gambar 3a). Pengunjung Embung A ITERA diklasifikasikan berdasarkan status perkawinan mereka, yaitu menikah dan lajang (Gambar 3b). Perolehan data berdasarkan status perkawinan adalah 32\% menikah, 54\% lajang, dan tanpa keterangan sekitar $14 \%$.

Persentase yang paling dominan dari latar belakang pendidikan adalah Sekolah Menengah Atas (SMA) dan Sekolah Menengah Kejuruan sekitar 75\%, kemudian dari lulusan strata 1 dengan persentase $14 \%$ dan pengunjung dengan latar belakang pendidikan Sekolah Menengah Pertama (SMP) dengan persentase 9\%, dan tanpa keterangan sekitar 4\% (Gambar 3c). Jumlah 4\% pengunjung tidak memberikan keterangan karena

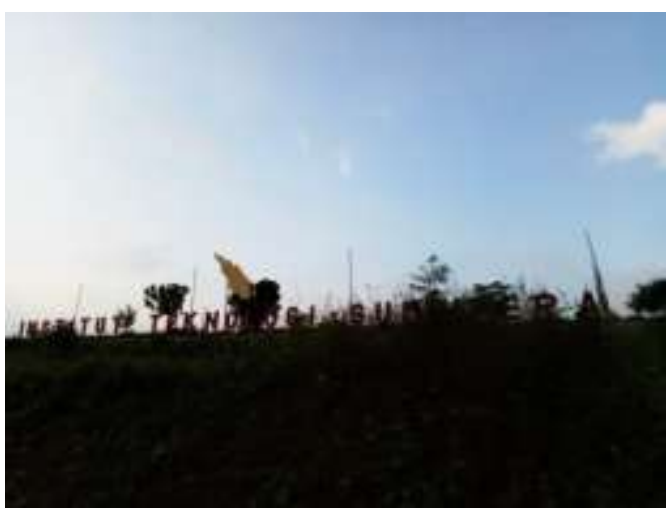

b. Landmark Embung A ITERA

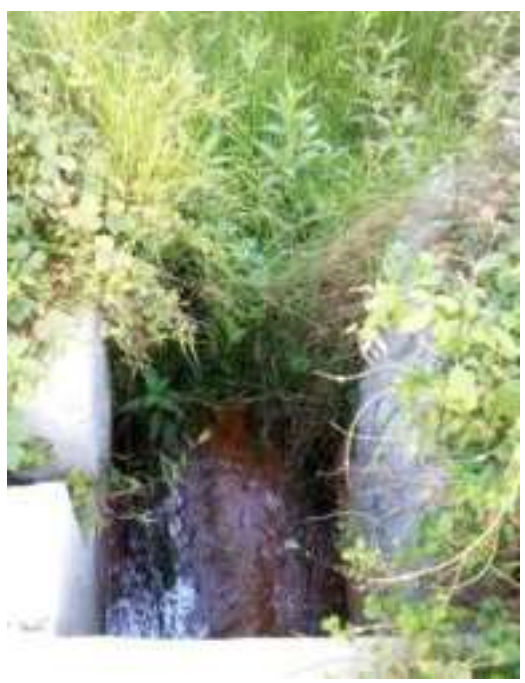

d. Inlet di Embung A ITERA

Gambar 2. Kondisi Umum Embung A ITERA

Pengelolaan lanskap adalah upaya untuk mengatur, menggunakan, melestarikan, mengawasi, mengendalikan, dan mengembangkan lingkungan yang bermanfaat bagi manusia dan makhluk hidup lainnya. Manajemen terkait erat dengan keprihatinan antara bahasan ekologis, ekonomi, dan sosial-budaya (Arifin, dan Arifin, 2005).

Latar Belakang Sosial Pengunjung di Embung A ITERA

Data kuesioner yang disebar berjumlah 100 kuesioner di Embung A ITERA dengan waktu pengambilan data pada pertanyaan dalam kuesioner bersifat tertutupsaat kondisi pengisian. Dominasi pengunjung yang datang ke Embung A adalah 75 orang dengan latar belakang pendidikan SMA/SMK pada kunjungan pukul 15.00-17.00 WIB. Data menyatakan bahwa $50 \%$ pengunjung menghabiskan waktu untuk mengunjungi Embung A ITERA yaitu sebulan sekali dan $24 \%$ pengunjung mengunjungi Embung A ITERA 2-5 kali berkunjung dalam satu minggu, dan sekitar $24 \%$ pengunjung menjelaskan bahwa mereka mengunjungi Embung A ITERA satu minggu satu kali. 
Data ini menunjukkan bahwa pengunjung paling sering mengunjungi Embung A ITERA selama rentang waktu satu bulan satu kali (Gambar 3d).

Potensi rekreasi dapat dikembangkan dari sisi psikologis pengunjung. Pengun jung dapat menilai jenis, bentuk, dan elemen lanskap yang lebih disukai serta bagaimana pengaruh pemilihan tersebut dari latar belakang kesejahteraan pengunjung. Saran untuk menilai preferensi lanskap, dapat dinyatakan dalam penilaian yang subjektif pada faktor potensi rekreasi. Faktor yang mempengaruhi dalam preferensi lanskap adalah faktor fisiologis, psikologis, dan sosial-budaya. Faktor fisiologis mengacu pada persepsi yang dihasilkan dari organ sensorik. Lanskap dapat dirasakan secara visual dengan stimulasi akustik, pensiuman, pengecapan, dan indera sentuhan. Stimulus sensorik diproses dalam sistem saraf pusat serta terhubung dengan perasaan. Faktor psikologis mengacu pada pengetahuan, pengalaman, emosional, dan motivasi dalam keadaan tertentu. Dapat diasumsikan bahwa preferensi lanskap kesatuan yang dinamis antara pikiran manusia dan lingkungannya (Mühl, 2020).

\section{Hasil Analisis Data Persepsi dan Preferensi Pengunjung di Embung A ITERA}

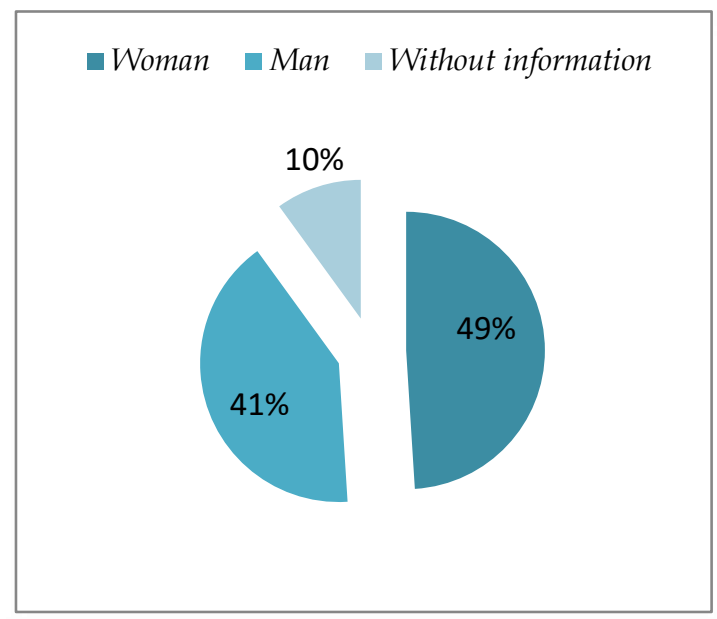

a. Dominansi Pengunjung Berdasarkan Jenis Kelamin

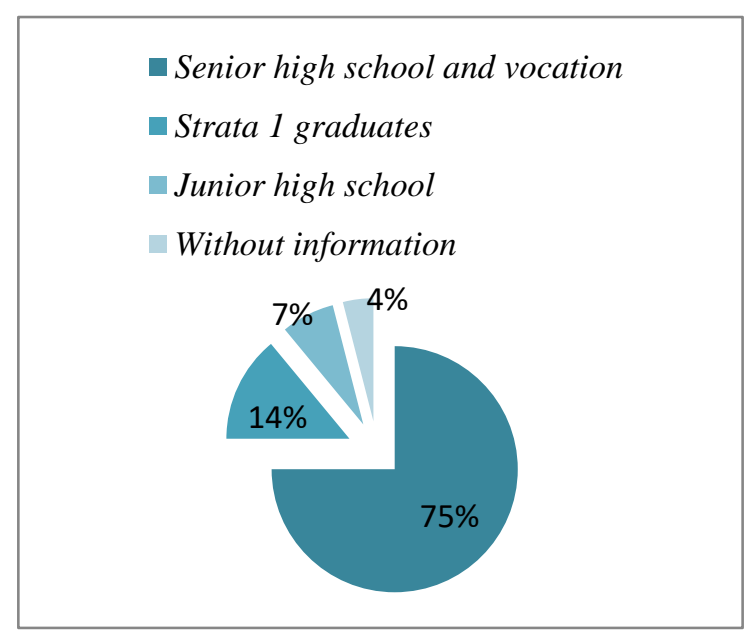

c. Dominansi Pengunjung Berdasarkan Latar Belakang Pendidikan
Pengelompokkan parameter dalam kuesioner penelitian, dibagi menjadi PP1 hingga PP12. Informasi PP1 terkait dengan kebersihan lingkungan Embung A ITERA, PP2 menjaga keindahan Embung A ITERA lingkungan, PP3 memelihara Embung A ITERA, PP4 mencegah dan mengurangi kerusakan lingkungan Embung A ITERA, PP5 kebersihan lingkungan limbah, PP6 partisipasi dalam pengelolaan Embung A ITERA, kesediaan PP7 untuk mengelola Embung A ITERA, partisipasi aktif PP8 dalam manajemen Embung A ITERA, PP9 partisipasi dalam mengelola Embung A ITERA, bantuan materi PP10 uang dari pengunjung ke Embung A ITERA, Tiket pembayaran PP11, dan harga tiket masuk PP12 ke area Embung A ITERA (Tabel 1).

Indeks korelasi dari data persepsi dan preferensi untuk pengelolaan lanskap di Embung A ITERA menunjukkan data korelasi antara pertanyaan dalam kuesioner yang berkaitan dengan persepsi responden tentang klasifikasi pertanyaan tentang pengelolaan Embung A ITERA dengan tingkat signifikansi $1 \%$. Nilai korelasi tertinggi atau variabel hubungan pada pernyataan kebersihan lingkungan dan keindahan lingkungan sangat 0,915 (positif).

Nilai hubungan variabel kebersihan lingkungan berkorelasi dengan menjaga ketertiban lingkungan

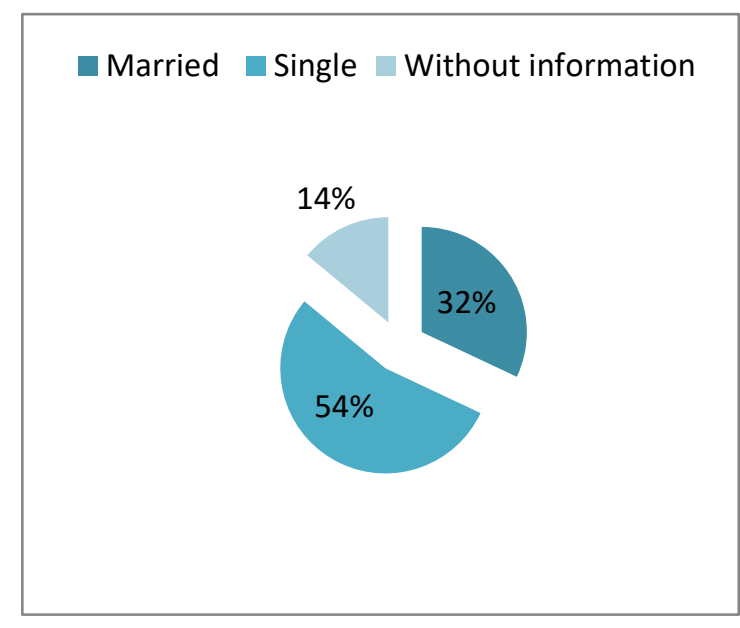

b. Dominansi Pengunjung Berdasarkan Status Pernikahan

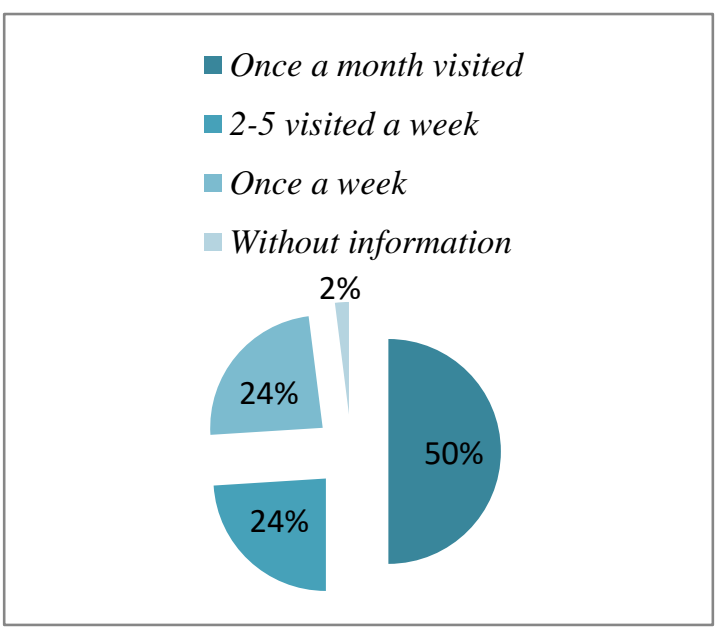

d. Dominansi Pengunjung Berdasarkan Waktu Kunjungan

Gambar 3. Latar Belakang Sosial Pengunjung di Embung ITERA 
dengan nilai 0,890 (positif). Korelasi tertinggi berikutnya adalah mempertahankan Embung A ITERA lainnya dengan mencegah dan mengurangi kerusakan pada Embung A ITERA 0.879 lingkungan (positif). Dari data menunjukkan bahwa jaringan dalam pengelolaan dengan nilai tertinggi adalah menjaga kebersihan lingkungan Embung A ITERA yang merupakan persepsi pengunjung dengan nilai 0,95 (positif) (Tabel 1). Pengelolaan lanskap dilakukan dengan mengembangkan pemahaman tentang faktor sosial yang multikultural, kosmopolitan, dan beragam secara ekonomi. Eksplorasi pengelolaan terdiri dari tiga strategi, yaitu pendidikan dan peraturan yang merupakan titik awal yang baik untuk mengembangkan pendekatan alternatif untuk pengelolaan lanskap (Suckall et al., 2009).

Data menunjukkan terdapat korelasi yang positif sebesar 0.95 dari PP1 dan PP2, artinya pengunjung setuju terhadap hubungan keindahan embung dengan kebersihan embung. Selanjutnya, dengan korelasi positif sebesar 0,558 terdapat hubungan antara PP 11 dan PP12 yaitu berkaitan dengan pengunjung yang dikenakan biaya pembayaran (Tabel 1). Pengunjung memilih untuk memberikan pembayaran dengan nilai tiket tertentu untuk memasuki area embung, sehingga dapat dinyatakan bahwa terdapat nilai tawar rekreasi di Embung A ITERA.

Rekomendasi Manajemen Lanskap Embung A Berdasarkan Persepsi dan Preferensi Masyarakat
Analisis hasil kuesioner yang diperoleh dari perhitungan data persepsi Embung A ITERA adalah bahwa pengunjung memiliki kecenderungan tertarik pada elemen air dan pandangan Embung A ITERA dengan waktu tertentu. Ini menunjukkan bahwa peran manajemen akan diarahkan pada konsep estetika di Embung A ITERA. Data menunjukkan bahwa pengunjung menginginkan fasilitas tambahan seperti tempat sampah, tempat duduk, dan tempat parkir.

Persepsi terhadap keindahan embung relatif sama, yaitu pengunjung memberikan kategori penilaian yang indah di embung karena adanya elemen pendukung alami, seperti sunset. Persepsi tersebut menunjukkan bahwa desain embung saat ini belum secara utuh dapat memengaruhi pengunjung untuk datang karena keindahan material lanskap didalamnya. Hasil wawancara menunjukkan pengunjung melakukan kunjungan ke Embung A ITERA karena pada area tersebut tidak ada ruang terbuka hijau maupun biru sebagai fasilitas untuk melakukan rekreasi singkat berkumpul bersama. Selain itu, material pendukung dalam area Embung A ITERA yang paling menarik adalah elemen air dan area sekitar embung.

Lanskap dengan lingkup lingkungan mikro, untuk menganalisis pengetahuan tentang interaksi unsur-unsur pendukungnya. Lanskap adalah suatu keadaan, yang mencerminkan konsekuensi dari proses dan juga realitas yang berubah dan dinamis (Konkoly-Gyuró, 2018). Lanskap berkontribusi pada peningkatan kualitas hidup

Tabel 1. Indeks Korelasi Lanskap Manajemen di Embung A ITERA

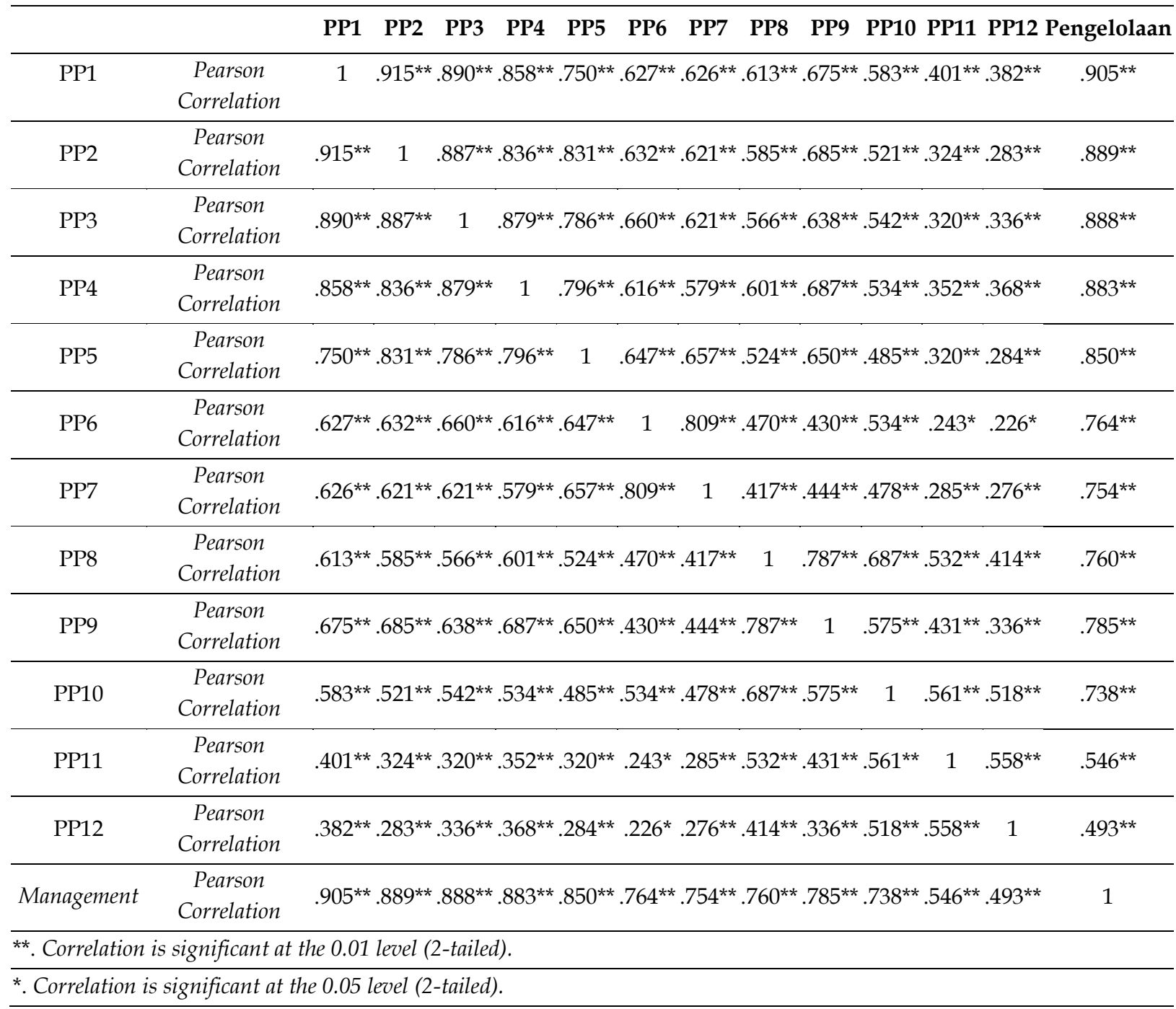


masyarakat melalui penyeiaan jasa estetika, peluang rekreasi, air, makanan, dan pengaturan iklim. Karakter lanskap merupakan interaksi antara faktor alam dan manusia (Zoderer et al., 2019).

Pengunjung Embung memiliki tingkat pemahaman yang baik dalam hal menjaga kebersihan dan keamanan. Ini bisa dilihat dari uraian jawaban untuk melindungi lingkungan embung dari limbah. Selain itu, saran untuk mengendalikan rumput liar harus dilakukan setiap saat.

Berdasarkan hasil korelasi lanskap terhadap pengelolaan Embung A didapatkan bahwa dalam PP6 adalah persepsi pengunjung terhadap komponen pengelolaan menunjukkan bahwa pengunjung bersedia berpartisipasi dalam pekerjaan pengelolaan (Tabel 1). Hasil penelitian menunjukkan terdapat partisipasi individu yang dapat dilakukan oleh pengunjung Embung A ITERA. Partisipasi individu yaitu dengan menjaga kebersihan, ketertiban, dan menjaga keindahan area Embung A. Hasil wawancara singkat mengenai partisipasi individu yang berkaitan dengan kebersihan akan berhubungan dengan penyediaan fasilitas serta petugas kebersihan yang meliputi penyediaan tempat sampah dan petugas kebersihan yang bekerja secara terus menerus untuk menjaga keberlangsungan kebersihan area embung. Kategori saat ini dalam material lanskap atau nit lanskap dapat diketahuo berdasarkan karakteristik kuantitatif dan keadaan perseptual dapat dinilai dari kualitatif yaitu karakter visual dan emosional. Sehingga, sangat erat kaitan lanskap yang terdiri dari unsur alam dan budaya atau antropogenik (Konkoly-Gyuró, 2018).

Partisipasi masyarakat yang berkaitan dengan menjaga ketertiban juga berhubungan dengan penyediaan fasilitas yang meliputi ketersediaan area parkir agar dapat menjaga ketertiban sarana transportasi dari pengunjung. Selain itu, pengunjung bersedia dalam pencegahan individu untuk tidak melakukan kerusakan atau praktik vandalisme di dalam area Embung A ITERA. partisipasi pengunjung dalam menjaga keindahan embung adalah dengan tidak merusak vegetasi yang ada. Dari perspektif budaya, pemandangan embung sangat penting bagi aktivitas pengunjung di Embung ITERA. Mereka mencontohkan, nilai estetika yang sangat baik berasal dari pemandangan indah dan area yang dapat berfungsi sebagai sumber daya untuk pariwisata dan pendidikan lingkungan (ILEC, 2007). Fasilitas dan atraksi mendukung hasil persepsi dan preferensi pengunjung dalam kawasan wisata air. Daya tarik yang utama adalah lanskap perairan dengan vegetasi tepian yang serba guna serta perairan yang luas dengan pemandangan pendukung lanskap alami. Preferensi pengunjung tertinggi adalah pada faktor perairan yang bersih, dan tenang. Implikasi pengelolaan di area perairan jika volume penggunaan tinggi, maka kualitas infrastruktur rekreasi harus ditingkatkan menjadi baik pula (Mühl, 2020).

Lanskap dengan kualitas estetika sedang lebih membuat pengunjung merasa nyaman dan aman. Lanskap ini juga lebih mudah untuk diukur keindahannya. Pengunjung menyukai beberapa tipe lanskap karena terdapat elemen tambahan dari hardscape material berupa air, jembatan dan catwalk, sehingga terkesan mengurangi kesan monoton dari pohon dan semak yang terdapat di sepanjang perjalanan tracking. Elemen air pada lanskap ini statis, sehingga memberikan perasaan tenang bagi pengunjung sehingga menciptakan suasana nyaman.
Lanskap dengan kualitas estetika tinggi paling disukai pengunjung karena memiliki unsur air terjun yang mengalir secara dinamis. Hal tersebut membuat pengunjung terkesan dan suasana objek yang terasa hidup. Pengunjung merasakan kenyamanan karena merasa aman karena jarak pandang lanskap yang jauh dan melebar, sehingga membuat pengunjung betah untuk berlama tinggal pada lanskap tersebut (Febriana dan Kaswanto, 2015).

Ruang terbuka biru bermanfaat untuk menampung air hujan dan dapat dirancang dalam bentuk danau buatan atau kolam retensi. Selain berfungsi sebagai sumber daya air, danau buatan juga dapat berfungsi sebagai area konservasi flora dan fauna. Selain itu, danau dapat digunakan sebaga area peningkatan serapan karbon untuk pendinginan udara, dan bernilai untuk menambah estetika lanskap. Area dengan bentuk wilayah bergelombang, sangat sesuai di desain sebagai cekungan badan air (Faradilla, et. al., 2017)

Penetapan prosedur yang melibatkan masyarakat secara umum dalam manajemen lanskap dengan tahapan perencanaan dan perlindungan padalanskap. Partisipasi publik diperlukan sebagai pendekaan berbasis pakar yang memiliki nilai lanskap dengan faktor sikap dan preferensi masyarakat yang dapat di ekspresikan dalam lanskap (Zoderer et al., 2019). Prioritas utama dalam strategi pengelolaan untuk membuat aturan pengembangan kawasan permukiman atau pengembangan properti dilakukan dengan analisis faktor kelemahan dan ancaman. Strategi aturan pengembangan kawasan dapat menjadi solusi pembangunan berkelanjutan sehingga, jumlah luasan ruang terbuka biru setiap tahunnya bertambah seiring dengan bertambahnya jumlah area terbangun (Arkham et. al., 2014).

Model yang diusulkan dalam makalah ini membahas masalah dengan cara analisis faktor multi-sosial selama pengumpulan da ta. Kesulitan yang dialami masyarakat untuk berpartisipasi dalam mengisi kuesioner. Kuisioner dibagikan dalam jangka waktu yang lebih lama, yaitu di pagi dan sore hari. Waktu itu dipilih ketika banyak orang melakukan kegiatan di sekitar Embung A ITERA. Selain itu, responden harus dipilih dan didampingi saat mengisi kuesioner. Kegiatan penelitian ini mengakui rekreasi sebagai fenomena yang kompleks, dengan mempertimbangkan sejumlah kegiatan di luar ruangan, bersifat multidimensi: termasuk aspek alam, sosial dan ekonomi.

Rekomendasi pengelolaan yang sesuai untuk Embung A adalah dengan melibatkan pengelolaan institusi yang harus memiliki tata tertib, peraturan, dan SOP (standard of procedure) serta penjadwalan dalam pemeliharaan ideal dan fisik yang jelas. Keterlibatan masyarakat dapat didampingi oleh pengelola resmi dari institusi sehingga dapat berjalan beriringan atau kolaborasi yang tepat. Keterlibatan masyarakat yang dapat dimasukkan dalam proses pengelolaan adalah berkaitan dengan partisipasi dalam menjaga kebersihan, ketertiban, dan keindahan area sekitar Embung A ITERA. Sehingga partisipasi masyarakat dalam pengelolaan dapat diterapkan dengan mudah untuk keberlanjutan keberadaan Embung A ITERA. 


\section{SIMPULAN}

Simpulan penelitian menunjukkan latar belakang pengunjung embung A ITERA didominasi oleh masyarakat sekitar Bandar Lampung dengan rentang usia 15-25tahun yang melakukan aktifitas kegiatan olahraga. Persepsi, preferensi, dan rekomendasi dari hasil penelitian ini adalah sebagai berikut:

1. Pengunjung memiliki preferensi untuk menikmati keindahan Embung A dengan menikmati lanskap berikut dengan pelengkap sinar mata

2. Persepsi pengunjung terhadap nilai estetika Embung A ITERA relatif sama berkaitan dengan estetika, yaitu pengunjung memberikan kategori penilaian yang indah karena unsur pendukungnya, seperti matahari terbenam. Persepsi ini menunjukkan desain embung tidak dapat mempengaruhi pengunjung untuk datang ke Embung A ITERA. Daya tarik paling utama adalah area estetika dari ruang terbuka hijau dan elemen pendukung cahaya.

3. Rekomendasi untuk manajemen lanskap Embung A adalah meningkatkan keindahan, kebersihan, kenyamanan, fasilitas pendukung seperti banku taman, lebih mementingkan keamanan dan kenyamanan area.

\section{UCAPAN TERIMA KASIH}

Penelitian ini didukung oleh Hibah Penelitian Smart ITERA dengan nomor hibah B375/IT9.C1/PT.01.03/2019. Kami berterima kasih kepada Institut Teknologi Sumatera atas dukungannya. Kami berterima kasih kepada reviewer Jurnal Lanskap Indonesia karena telah memberikan kritik dan komentar yang membangun.

\section{DAFTAR PUSTAKA}

Arifin, H.S., Arifin, N.H.S. 2005. Pemeliharaan Taman. Cetakan VIII. Edisi Revisi. Jakarta: Penebar Swadaya.

Damanik, J., Helmut, F.W. 2006. Perencanaan Ekowisata dari Teori ke Aplikasi. Penerbit C.V. Andi Offset (Penerbit Andi). Yogyakarta.

Faradilla, E., Kaswanto, dan; Arifin, H. S. 2017. Analisis Kesesuaian Lahan Untuk Ruang Terbuka Hijau Dan Ruang Terbuka Biru Di Sentul City, Bogor. Jurnal Lanskap Indonesia, 9(2), 101-109. doi:10.29244/jli.2017.9.2.101-109

Febriana, N.P.R., Kaswanto. 2015. Tourism Track Management of Cibeureum Waterfall as a Provider of Landscape Beautification Service at Gunung Gede Pangrango National Park. Procedia Environmental Sciences, 24(3), 174-183. https://doi.org/10.1016/j. proenv.2015.03.023

Hs Arkham, Kaswanto, dan Arifin, H.S. 2014. Strategi Pengelolaan Lanskap Ruang Terbuka Biru Di Daerah Aliran Sungai Ciliwung. Jurnal Lanskap Indonesia, 6(1), 101-109.doi.org/10.29244/jli.2014.6.1.1-5

ILEC. 2007. Intergrated Lake Basin Management: An Introduction. International Lake Environment Committee Foundation, Kusatsu.

Komossa, F., Wartmann, F.M., Kienast, F., Verburg, P.H. 2020. Comparing outdoor recreation preferences in periurban landscapes using different data gathering methods. Landscape and Urban Planning, 199 (February),
103796. https://doi.org/10.1016/ j.landurbplan/ 2020.103796

Konkoly-Gyuró, É. 2018. Conceptualisation and perception of the landscape and its changes in a transboundary area. A case study of the Southern German-French borderland. Land Use Policy, 79 (May), 556-574. https://doi.org/10.1016/j.landusepol.2018.08.019

Kulczyk, S., Woźniak, E., Derek, M. 2018. Landscape, facilities and visitors: An integrated model of recreational ecosystem services. Ecosystem Services, 31, 491-501. https://doi.org/10.1016/j.ecoser.2018.02.016

Lin, L., Homma, R., Iki, K. 2018. Preferences for a lake landscape: Effects of building height and lake width. Environmental Impact Assessment Review, 70 (October 2017), 22-33. https://doi.org/10.1016/ j.eiar.2018.03.001

Mühl, S. 2020. Landscape and infrastructure preferences of recreational rowers in Germany. Journal of Outdoor Recreation and Tourism, 29 (June 2019), 100271. https://doi.org/10.1016/j.jort.2019.100271

Ramyar, R. 2019. Social-ecological mapping of urban landscapes: Challenges and perspectives on ecosystem services in Mashhad, Iran. Habitat International, 92 (September), 102043. http//doi.org/10.1016/j. habitatint.2019.102043

Sever, I., Verbič, M. 2019. Assessing recreational values of a peri-urban nature park by synthesizing perceptions and preferences of trail users. Journal of Environmental Psychology, 63 (June 2018), 101-108. http/ / doi.org/ 10.1016/j.jenvp.2019.04.010

Suckall, N., Fraser, E.D.G., Cooper, T., Quinn, C. 2009. Visitor perceptions of rural landscapes: A case study in the Peak District National Park, England. Journal of Environmental Management, 90 (2), 1195-1203. https://doi.org/10.1016/j.jenvman.2008.06.003

Zoderer, B.M., Tasser, E., Carver, S., Tappeiner, U. 2019. An integrated method for the mapping of landscape preferences at the regional scale. Ecological Indicators, 106 (October 2018), 105430. https://doi.org/10.1016 /j.ecolind.2019.05.061 